\title{
MENINGKATKAN KUALITAS PEMBELAJARAN MELALUI ACTIVE LEARNING IN HIGH EDUCATION (ALIHE) PADA MATA KULIAH PENDIDIKAN IPA SD DI JURUSAN PGSD FIP UNJ
}

\author{
A. R. Supriatna \\ email: arsupriatna@yahoo.com \\ Jurusan PGSD, FIP Universitas Negeri Jakarta
}

\begin{abstract}
Abstrak: Perbaikan kualitas pembelajaran, khususnya pada perkuliahan IPA di PGSD FIP UNJ, belum menggunakan sepenuhnya pembelajaran aktif di perguruan tinggi atau Active learning in higher education (ALIHE). Dosen lebih banyak menguasai perkuliahan dari pada mengarahkan mahasiswanya aktif. Penelitian ini bertujuan untuk meningkatkan kualitas pembelajaran melalui Active Learning In Higher Education (ALIHE) pada mata kuliah pendidikan IPA SD di jurusan PGSD FIP UNJ. Penelitian ini dilakukan Jurusan PGSD FIP UNJ pada bulan Februari hingga Juni 2012. Metode penelitian ini menggunakan Penelitian Tindakan (Action Research). Teknik pengumpulan data menggunakan instrumen berupa lembar observasi kegiatan mahasiswa, yang telah disusun secara bersama-sama dengan tim dosen IPA pengampu mata kuliah pendidikan IPA SD. Hasil dari penelitian ini adalah bahwa pembelajaran melalui Active Learning In Higher Education (ALIHE) pada mata kuliah pendidikan IPA SD di jurusan PGSD FIP UNJ dapat (1) meningkatkan kemampuan pembelajaran terkait dengan perilaku dosen atau pendidik, serta dampak belajar mahasiswa calon guru dalam pembelajaran IPA SD; (2) meningkatkan iklim pembelajaran yang sesuai dengan mata kuliah pendidikan IPA SD; (3) dosen atau dosen bersama mahasiswa dapat mendesain materi pembelajaran dan media pembelajaran yang dapat meningkatkan hasil belajar, khususnya pada perkulihan pendidikan IPA pada mahasiswa PGSD FIP UNJ; serta (4) dapat memilih sistem pembelajaran yang lebih sesuai khusunya pada mata kuliah pendidikan IPA SD.

Kata kunci: Peningkatan Kualitas Pembelajaran, Active Learning in High Education (ALIHE).

\section{Improving Instructional Quality Through Active Learning In High Education (ALIHE) on Natural Science Education Course}

\begin{abstract}
Abstrak: The improvement of instructional quality, particularly in the Natural Science Course, in Primary School Teacher Education Departement of the School of Education, State University of Jakarta, has not well implemented active learning as required in ALIHE. The lecture plays more role directing the students rather than motivating the students to be active learning. The purpose of this research was to improve the instructional quality by implementing ALIHE in this Course. Employing action research method, the research was conducted at Primary School Teacher Education Departement of the School of Education, State University of Jakarta, as from February through June 2012. The data were collected using the observatuin sheets prepared in collaboration with Natural Science Lecturers responsible for the Course of Natural Science Education for Primary School. The findings concluded thet ALIHE strategy can (1) improve the instructional quality including the lecture's performance and the learning effects for the students, (2) improve the appropriate instructional climate, (3) enable the the lecture or the lecture and the students design instructional materials and media which improve the learning achiievement, and (4) enable the lecture to determine more suitable instructional system.
\end{abstract}

Key words: Instructional quality improvement, Active Learning in High Education, , instructional climate, instructional system design.

\section{PENDAHULUAN}

Perbaikan kurikulum di PGSD FIP UNJ sebagai salah satu perbaikan sistem pembelajaran sudah dilakukan secara kontinu. Masing-masing rumpun mata kuliah terus memperbaiki dan mengembangkan garis besar mata kuliah (course outline). Pada mata kuliah Pendidikan IPA SD kontinuitas revisi kuriku- lum untuk kearah perbaikan, dirasakan masih belum maksimal. Pantauan atau penelitian secara formal jarang dilakukan untuk melihat apakah desain mata kuliah pendidikan IPA SD berhasil atau tidak, perlu diperbaiki atau disempurnakan. Garis besar mata kuliah Pendidikan IPA berdasarkan desain pembelajaran yang aktif di Jurusan PGSD FIP UNJ belum dirancang dan diterapkan dalam perkulihan secara maksimal. 
Perbaikan kualitas pembelajaran, khususnya pada perkuliahan IPA di PGSD FIP UNJ, belum menggunakan sepenuhnya pembelajaran aktif di perguruan tinggi atau Active learning in higher education (ALIHE). Dosen lebih banyak menguasai perkuliahan dari pada mengarahkan mahasiswanya aktif. Pembelajaran lebih berorientasi buku teks, untuk penguasaan materi. Sebagian besar mahasiswa PGSD dalam perkuliahan masih mengandalkan materi yang diberikan oleh dosen. Seharusnya mahasiswa PGSD lebih aktif dan mandiri untuk mencari dan mengumpulkan materi sebagai bekal dirinya.

Desain pembelajaran aktif diantaranya meliputi desain tujuan pembelajaran, materi pembelajaran, strategi pembelajaran dan evaluasi pembelajaran. Disain pembelajaran IPA SD di Jurusan PGSD yang tertera dalam kurikulum masih bersifat umum dan luas, kemudian dikembangkan ke dalam silabus, kontrak kuliah atau lainnya. Selanjutnya desain ini diterapkan pada setiap perkuliahan yang tersusun pada satuan acara perkuliahan atau lainnya. Penerapan desain pembelajaran aktif belum sepenuhnya diterapkan pada mata kuliah Pendidikan IPA SD di Jurusan PGSD FIP UNJ, baik dari segi persiapan, proses maupun produk maupun pembelajarannya. Sejauhmana hasil belajar mahasiswa yang mengikuti perkuliahan di Jurusan PGSD FIP UNJ yang menerapkan desain pembelajaran aktif? Bagaimana pelaksanaan dan evaluasi perkuliahan yang menerapkan pembelajaran aktif di perguruan tinggi atau Active Learning In Higher Education (ALIHE) perlu diteliti secara mendalam.

\section{Rumusan Masalah}

Berdasarkan uraian latar belakang tersebut di atas, maka permasalahan yang dirumuskan dalam penelitian tindakan ini adalah: (1) adakah peningkatan kualitas pembelajaran terkait dengan perilaku dosen atau pendidik dalam pembelajaran IPA SD yang menggunakan ALIHE? (2) Adakah peningkatan kualitas pembelajaran terkait dengan perilaku dan dampak belajar mahasiswa calon guru dalam pembelajaran IPA SD yang menggunakan ALIHE? (3) Adakah peningkatan iklim pembelajaran yang sesuai dengan mata kuliah pendidikan IPA SD yang menggunakan ALIHE? (4) Bagaimana mendesain materi pembelajaran dan media pembelajaran yang dapat meningkatkan hasil belajar mahasiswa PGSD FIP UNJ? (5) Bagaimana memilih media pembelajaran yang lebih sesuai pada mata kuliah pendidikan IPA SD?

\section{Tujuan Penelitian}

Penelitian dilakukan untuk mengimplementasikan pengembangan desain pembelajaran dalam mata kuliah Pendidikan IPA SD di Jurusan PGSD FIP
UNJ melalui ALIHE, bertujuan untuk meningkatkan kualitas pembelajaran, pada aspek-aspek: (1) kemampuan pembelajaran terkait dengan perilaku dosen atau pendidik dalam pembelajaran IPA SD, (2) kemampuan pembelajaran terkait dengan perilaku dan dampak belajar mahasiswa calon guru dalam pembelajaran IPA SD, (3) iklim pembelajaran yang sesuai dengan mata kuliah pendidikan IPA SD, (4) mendesain materi pembelajaran dan media pembelajaran yang dapat meningkatkan hasil belajar mahasiswa PGSD FIP UNJ, dan (5) memilih media pembelajaran yang lebih sesuai pada mata kuliah pendidikan IPA SD.

\section{Kajian Pustaka}

\section{Pengertian ALIHE}

ALIHE singkatan dari Active Learning in Higher Education atau pembelajaran aktif di perguruan tinggi. Menurut Sadiman (2011), pembelajaran aktif di perguruan tinggi adalah pembelajaran aktif yang membuat mahasiswa dapat belajar secara aktif (active learning). Fokus pembelajaran dari apa yang dosen harus ajarkan bergeser pada apa yang harus dapat dilakukan mahasiswa setelah mengikuti perkuliahan. Pendapat ini sangat tepat untuk dilaksanakan, karena sistem diperguruan tinggi berlaku sistem kredit semester (SKS). Pada sistem SKS mahasiswa punya waktu tertentu untuk aktif di dalam kampus maupun di luar kampus. Pembelajaran aktif di perguruan tinggi memberi kesempatan mahasiswa untuk belajar secara aktif dan menerapkan dalam disiplin keilmuan atau kehidupan sehari-hari. Mahasiswa juga berkesempatan menunjukkan penguasaan keterampilan dan pengetahuannya.

Metode active learning merupakan suatu proses kegiatan belajar mengajar yang subjek didiknya terlibat secara intelektual dan emosional, sehingga siswa betul-betul berperan dan berpartisipasi aktif dalam melakukan kegiatan belajar sehingga tujuan pengajaran dapat dicapai lebih baik. Di perguruan tinggi, mahasiswa terlibat aktif bukan hanya secara intelektual dan emosi saja, akan tetapi aktif dalam merancang, melaksanakan, dan memperbaiki kegiatan pembelajarannya. Merancang yang dimaksud, yaitu mahasiswa tidak hanya ingin mengikuti keinginan dosennya atau rutinitas yang dilakukannya, tetapi memberi kontribusi terhadap rancangan yang akan dilakukan. Mahasiswa melaksanakan pembelajaran sebagai subjek, dan ikut memperbaiki kekurangan-kekurangan yang dirasakan dalam melakukan pembelajaran.

2. Pengertian Peningkatan Kualitas Pembelajaran

Kualitas pembelajaran secara operasional dapat diartikan sebagai intensitas keterkaitan sistemik dan sinergis dosen, mahasiswa, kurikulum dan bahan be- 
lajar, media, fasilitas, serta sistem pembelajaran dalam menghasilkan proses dan hasil belajar yang optimal sesuai dengan tuntutan kurikuler.

\section{METODE PENELITIAN}

\section{Jenis Penelitian}

Penelitian ini termasuk dalam Penelitian Tindakan Kelas (PTK) yang secara khusus bertujuan untuk meningkatkan kualitas pembelajaran pada mata kuliah pendidikan IPA SD melalui Active Learning In Higher Education (ALIHE) di jurusan PGSD FIP.

Penelitian tindakan adalah seperangkat dari ide-ide dan teknik yang dapat mengenalkan pada refleksi yang sistematis. Dengan kata lain, penelitian tindakan adalah cara untuk terus tumbuh dan belajar melalui pemanfaatan diri sendiri untuk memahami pengalaman. Tindakan perbaikan hasil belajar pada mata kuliah pendidikan IPA SD dapat dilakukan dengan penelitian tindakan menggunakan model Tindakan yang merupakan adopsi dari langkah-langkah yang dikembangkan oleh Teachers Network Leadership Institute (TNLI).

\section{Tempat dan Waktu Penelitian}

Penelitian ini dilakukan pada mahasiswa semester IV Jurusan PGSD FIP UNJ. Tindakan penelitian ini dilakukan selama 4 bulan, pada tahun akademik 2011/2012 semester II pada Februari 2012 sampai Juni 2012. Sedangkan pelaporan hasil penelitian pada Desember 2012.

\section{Prosedur Penelitian}

\section{a. Sumber Data}

Subjek yang digunakan untuk penelitian ini adalah mahasiswa-mahasiswa Jurusan PGSD FIP UNJ yang mengambil mata kuliah Pendidikan IPA SD. Penelitian ini dilakukan pada satu kelas yang berjumlah 40 orang, yaitu mahasiswa di kelas yang diampu peneliti dan team untuk mata kuliah Pendidikan IPA SD.

b. Teknik Pengumpulan Data

Penelitian ini melalui tahap-tahap wawancara, meliputi menentukan siapa saja yang diwawancarai, mempersiapkan wawancara, dan melakukan wawancara dan memelihara agar wawancara produktif.

Kemudian penelitian ini melakukan observasi (pengamatan). Instrumen pada penelitian ini adalah lembar observasi proses pembelajaran yang menggunakan proses pembelajaran yang menggunakan active learning in high education (ALIHE). Untuk menyusun lembar observasi dibuat dimensi dan indikator pada kisi-kisi, sebagai berikut:

1. Definisi konseptual

Kualitas pembelajaran secara operasional dapat diartikan sebagai intensitas keterkaitan sistemik dan sinergis dosen, mahasiswa, kurikulum dan bahan belajar, media, fasilitas, dan sistem pembelajaran dalam menghasilkan proses dan hasil belajar yang optimal sesuai dengan tuntutan kurikuler.

\section{Definisi operasional}

Skor yang diperoleh dari hasil observasi pada pembelajaran yang terkait dengan kualitas pembelajaran, sebagai intensitas keterkaitan sistemik dan sinergis dosen, mahasiswa, kurikulum dan bahan belajar, media, fasilitas, dan sistem pembelajaran.

\section{Kisi-kisi Instumen}

Kisi-kisi instrumen proses pembelajaran yang menggunakan active learning in high education (ALIHE) yang terdapat pada tabel 1.

Tabel 1. Kisi-Kisi Instrumen Proses Pembelajaran ALIHE

\begin{tabular}{|c|c|c|}
\hline Dimensi & Indikator & $\begin{array}{l}\text { No. } \\
\text { Soal }\end{array}$ \\
\hline \multirow[t]{5}{*}{ Kinerja dosen } & $\begin{array}{l}\text { (a) Membangun persepsi dan sikap } \\
\text { positif mahasiswa terhadap belajar } \\
\text { dan profesi pendidik }\end{array}$ & 1 \\
\hline & (b) Menguasai disiplin ilmu & 2 \\
\hline & $\begin{array}{l}\text { (c) Dosen perlu memahami keunikan } \\
\text { setiap mahasiswa dengan segenap } \\
\text { kelebihan, kekurangan, dan kebutuh- } \\
\text { annya. }\end{array}$ & 3 \\
\hline & $\begin{array}{l}\text { (d) Menguasai pengelolaan pembela- } \\
\text { jaran yang mendidik berorientasi pada } \\
\text { mahasiswa tercermin dalam kegiatan } \\
\text { merencanakan, melaksanakan, serta } \\
\text { mengevaluasi dan memanfaatkan } \\
\text { hasil evaluasi pembelajaran secara } \\
\text { dinamis untuk membentuk kompe- } \\
\text { tensi mahasiswa yang dikehendaki, }\end{array}$ & 4,5 \\
\hline & $\begin{array}{l}\text { (e) Mengembangkan kepribadian dan } \\
\text { keprofesionalan sebagai kemampuan } \\
\text { untuk dapat mengetahui, mengukur, } \\
\text { dan mengembang-mutakhirkan ke- } \\
\text { mampuannya secara mandiri. }\end{array}$ & 6 \\
\hline \multirow[t]{6}{*}{$\begin{array}{l}\text { Mahasiswa } \\
\text { calon guru }\end{array}$} & $\begin{array}{l}\text { (a) Memiliki persepsi dan sikap positif } \\
\text { terhadap belajar }\end{array}$ & 7 \\
\hline & $\begin{array}{l}\text { (b) Mau dan mampu mendapatkan } \\
\text { dan mengintegrasikan pengetahuan } \\
\text { dan keterampilan serta membangun } \\
\text { sikapnya }\end{array}$ & 8 \\
\hline & $\begin{array}{l}\text { (c) Mau dan mampu memperluas } \\
\text { serta memperdalam pengetahuan } \\
\text { dan keterampilan serta memantapkan } \\
\text { sikapnya }\end{array}$ & 9 \\
\hline & $\begin{array}{l}\text { (d) Mau dan mampu menerapkan } \\
\text { pengetahuan, keterampilan, dan } \\
\text { sikapnya secara bermakna. }\end{array}$ & 10 \\
\hline & $\begin{array}{l}\text { (e) Mau dan mampu membangun ke- } \\
\text { biasaan berpikir, bersikap, dan bekerja } \\
\text { produktif. }\end{array}$ & 11 \\
\hline & $\begin{array}{l}\text { (f) Mampu menguasai substansi dan } \\
\text { metodologi dasar keilmuan bidang } \\
\text { studinya. }\end{array}$ & 12 \\
\hline
\end{tabular}

Perspektif Ilmu Pendidikan - Vol. 27 Th. XVIII April 2013 


\begin{tabular}{|c|c|c|}
\hline Dimensi & Indikator & $\begin{array}{l}\text { No. } \\
\text { Soal }\end{array}$ \\
\hline \multirow[t]{4}{*}{$\begin{array}{l}\text { Mahasiswa } \\
\text { calon guru }\end{array}$} & $\begin{array}{l}\text { (g)Mampu menguasai materi ajar } \\
\text { mata pelajaran dalam kurikulum seko- } \\
\text { lah/satuan pendidikan sesuai dengan } \\
\text { bidang studinya. }\end{array}$ & 13 \\
\hline & $\begin{array}{l}\text { (h) Mampu memahami karakteristik, } \\
\text { cara belajar, bekal ajar awal, dan latar } \\
\text { belakang sosial kultural peserta didik } \\
\text { usia sekolah }\end{array}$ & 14 \\
\hline & $\begin{array}{l}\text { (i) Mampu menguasai prinsip, ran- } \\
\text { cangan, pelaksanaan, dan penilaian } \\
\text { pembelajaran yang mencerdaskan, } \\
\text { mendidik, dan membudayakan }\end{array}$ & 15 \\
\hline & $\begin{array}{l}\text { (j) Mampu menguasai strategi dan } \\
\text { teknik pengembangan kepribadian } \\
\text { dan keprofesionalan sebagai guru. }\end{array}$ & 16 \\
\hline \multirow[t]{2}{*}{$\begin{array}{l}\text { Iklim pembe- } \\
\text { lajaran }\end{array}$} & $\begin{array}{l}\text { (a) Suasana kelas yang kondusif bagi } \\
\text { tumbuh dan berkembangnya kegiatan } \\
\text { pembelajaran yang menarik, menan- } \\
\text { tang, menyenangkan dan bermakna } \\
\text { bagi pembentukan }\end{array}$ & 17,18 \\
\hline & $\begin{array}{l}\text { (b) Suasana kondusif bagi tumbuhnya } \\
\text { penghargaan mahasiswa calon guru } \\
\text { terhadap jabatan dan kinerja profe- } \\
\text { sional guru. }\end{array}$ & 19 \\
\hline \multirow{4}{*}{$\begin{array}{l}\text { Materi } \\
\text { pembela- } \\
\text { jaran yang } \\
\text { berkualitas }\end{array}$} & $\begin{array}{l}\text { (a) Kesesuaiannya dengan tujuan } \\
\text { pembelajaran dan kompetensi yang } \\
\text { harus dikuasa mahasiswa. }\end{array}$ & 20 \\
\hline & $\begin{array}{l}\text { (b) Materi pembelajaran sistematis dan } \\
\text { kontekstual. }\end{array}$ & 21 \\
\hline & $\begin{array}{l}\text { (c) Dapat mengakomodasikan parti- } \\
\text { sipasi aktif mahasiswa dalam belajar } \\
\text { semaksimal mungkin }\end{array}$ & 22 \\
\hline & $\begin{array}{l}\text { (d) Dapat menarik manfaat yang opti- } \\
\text { mal dari perkembangan dan kemajuan } \\
\text { bidang ilmu, teknologi, dan seni. }\end{array}$ & 23 \\
\hline \multirow{3}{*}{$\begin{array}{l}\text { Kualitas me- } \\
\text { dia pembela- } \\
\text { jaran }\end{array}$} & $\begin{array}{l}\text { (a) Dapat menciptakan pengalaman } \\
\text { belajar yang bermakna. }\end{array}$ & 24 \\
\hline & $\begin{array}{l}\text { (b) Mampu memfasilitasi proses in- } \\
\text { teraksi antara mahasiswa dan dosen, } \\
\text { mahasiswa dan mahasiswa, serta } \\
\text { mahasiswa dengan ahli bidang ilmu } \\
\text { yang relevan. }\end{array}$ & 25 \\
\hline & $\begin{array}{l}\text { (c) Media pembelajaran dapat mem- } \\
\text { perkaya pengalaman belajar maha- } \\
\text { siswa. }\end{array}$ & 26 \\
\hline
\end{tabular}

\section{c. Teknik Analisis Data}

Teknik analisis data menggunakan analisis data kualitatif. Analisis data kualitatif menghimpun, mengolah dan menganalisis lembar observasi dan catatan-catatan lapangan. Catatan lapangan didapat bersamaan dengan cara menggunakan lembar observasi, catatan lapangan, foto-foto atau melalui video.

Analisis data dilakukan terhadap data pemantau tindakan yang menggunakan lembar observasi kesesuaian ALIHE dan data kualitas pembelajaran. Analisis yang dikemukakan oleh Miles \& Huberman (1990), yakni melalui tahapan:

(1) Reduksi data, sebagai proses pemilihan, pemusatan perhatian pada penyederhanaan, pengabstrakan, dan transformasi data yang muncul pada catatan lapangan. Menurut Guba dan Lincoln (1981) pembuatan catatan: Pembuatan catatan lapangan, yaitu gambaran umum peristiwa yang telah diamati oleh peneliti. Catatan tentang satuan-satuan tematis yaitu catatan rinci tentang tema yang muncul dan catatan kronologis.

(2) Penyajian data, pada tahap ini peneliti banyak terlibat dalam kegiatan penyajian atau penampilan (display) dari data yang dikumpulkan.

(3) Penarikan kesimpulan.

\section{HASIL DAN PEMBAHASAN}

\section{Hasil Penelitian Tindakan 1}

\section{Tahap membuat komitmen}

Disepakati oleh mahasiswa dan dosen, kelas dibagi ke dalam 8 kelompok. Masing-masing kelompok sepakat untuk membahas satu pokok bahasan yang akan dipresentasikan atau disimulasikan. Masing-masing kelompok sudah sepakat untuk menggunakan strategi, metode atau model yang dapat mengaktifkan pembelajaran pada perkulihan IPA.

\section{Tahap perencanaan tindakan}

Pada tahap perencanaan yang oleh dosen pengampu melakukan: Mengaji ulang silabus mata kuliah Pendidikan IPA SD tahun ajaran yang lalu bersama tim pengampu mata kuliah sejenis, serta mendiskusikan rancangan pembuatan pembelajaran Aktif. Pengajian disepakati menggunakan pendekatan-pendekatan yang mengarah pada aktivitas mahasiswa pada setiap perkuliahan. Menghubungkan pengembangan silabus dengan tindakan berupa ALIHE. Silabus yang sudah disusun mengarah pada aktivitas mahasiswa dijelaskan dalam rencana harian perkuliahan.

\section{Tahap pelaksanaan tindakan}

Kinerja dosen, yang didapat diantaranya: Dosen belum dapat membangun persepsi dan sikap positif mahasiswa terhadap belajar dan profesi pendidik. Sudah menguasai disiplin ilmu dan dosen belum sepenuhnya memahami keunikan setiap mahasiswa dengan segenap kelebihan, kekurangan, dan kebutuhannya. Dosen sudah menguasai pengelolaan pembelajaran yang mendidik berorientasi pada mahasiswa tercermin dalam kegiatan merencanakan, melaksanakan, serta mengevaluasi dan memanfaatkan hasil evaluasi pembelajaran secara dinamis untuk membentuk kompetensi mahasiswa yang dikehendaki. Dosen belum melakukan pengembangan kepribadian dan keprofesionalan sebagai kemampuan untuk dapat mengetahui, mengukur, dan mengembangkan mu- 
takhirkan kemampuannya secara mandiri.

Perilaku dan dampak belajar mahasiswa calon guru dilihat dari kompetensinya. Hasil pantauan didapat, yaitu: (1) mahasiswa sudah memiliki persepsi dan sikap positif terhadap belajar; (2) mahasiswa belum dapat mengintegrasikan pengetahuan dan ketrampilan serta membangun sikapnya; (3) mahasiswa belum mampu memperluas serta memperdalam pengetahuan dan ketrampilan serta memantapkan sikapnya; (4) mahasiswa belum mampu menerapkan pengetahuan, ketrampilan, dan sikapnya secara bermakna; (5) mahasiswa belum mampu membangun kebiasaan berpikir, bersikap dan bekerja produktif; (6) mahasiswa sudah mampu menguasai substansi dan metodologi dasar keilmuan bidang studinya; (7) mahasiswa sudah mampu menguasai materi ajar mata pelajaran dalam kurikulum sekolah/satuan pendidikan sesuai dengan bidang studinya; (8) mahasiswa belum mampu memahami karakteristik, cara belajar, bekal ajar awal, dan latar belakang sosial kultural peserta didik usia sekolah; (9) mahasiswa belum mampu menguasai prinsip, rancangan, pelaksanaan, dan penilaian pembelajaran yang mencerdaskan, mendidik, dan membudayakan; dan (10) mahasiswa belum mampu menguasai strategi dan teknik pengembangan kepribadian dan keprofesionalan sebagai guru.

$1 \mathrm{klim}$ pembelajaran indikator yang didapat dan dilihat dalam pembelajaran, yaitu suasana sudah kelas yang kondusif bagi tumbuh dan berkembangnya kegiatan pembelajaran yang menarik, menantang, menyenangkan, dan bermakna bagi pembentukan profesionalitas kependidikan. Di samping itu, suasana kondusif bagi tumbuhnya penghargaan mahasiswa calon guru terhadap jabatan dan kinerja profesional guru.

Materi pembelajaran yang berkualitas dapat dilihat dari hasil pantauan yang menggunakan lembar observasi dan observasi langsung diantaranya, kesesuaiannya dengan tujuan pembelajaran dan kompetensi yang harus dikuasa mahasiswa. Materi pembelajaran belum tersusun secara sistematis dan kontekstual. Materi belum mengakomodasikan partisipasi aktif mahasiswa dalam belajar semaksimal mungkin. Materi belum sepenuhnya menarik manfaat yang optimal dari perkembangan dan kemajuan bidang ilmu, teknologi, dan seni.

Dalam memilih media pembelajaran yang lebih sesuai pada mata kuliah pendidikan IPA SD. Didapat hasil bahwa kualitas media pembelajaran tampak sudah mengarah menciptakan pengalaman belajar yang bermakna. Di samping itu sudah mampu memfasilitasi proses interaksiantara mahasiswa dan dosen, mahasiswa dan mahasiswa, serta mahasiswa dengan ahli bidang ilmu yang relevan. Pada salah satu kegiatan pembelajara media pembelajaran belum dapat memperkaya pengalaman belajar mahasiswa.

4. Tahap perencanaan tindakan kembali

Pada tahap ini melakukan pengamatan kegiatan kelas sambil mengumpulkan data dengan mengisi instrumen atau lembar observasi. Instrumen sebagai perbaikan pertanyaan pada instrumen berisi pertanyaan yang menyempurnakan kegiatan sebelumnya. Instrumen atau lembar observasi berisi kriteria pembelajaran yang muncul pada pembelajaran sebelumnya. 5. Tahap perbaikan tindakan

Seberapa jauh kekurangan dan tindak lanjut perbaikan yang akan dilakukan. Pada tahap ini, tindakan diperbaiki berdasarkan pengalaman kegiatan terdahulu. Terlaksana atau tidaknya tindakan perbaikan akan menentukan langkah berikutnya berupa pembuatan komitmen, seperti pada tahap 1 .

\section{Hasil Penelitian Tindakan Tahap 2}

\section{Tahap membuat komitmen}

Mahasiswa diminta untuk lebih aktif dan mengkritisi rancangan pembelajaran yang sudah disusun oleh dosen pengampu, seperti silabus dan rencana pelaksanaan perkuliahan. Disepakati oleh mahasiswa dan dosen, 4 kelompok yang akan melakukan pembelajaran untuk memperbaiki kekurangan pada tahap 1. Mahasiswa juga ikut memantau kegiatan perkulihan dipilih yang lebih terampil, misalnya khusus pengambilan gambar berupa foto atau video.

\section{Tahap perencanaan tindakan}

Pada tahap perencanaan, dosen pengampu melakukan perbaikan pada rencana harian perkuliahan ditentukan juga jenis-jenis kegiatan perkuliahan yang menggunakan ALIHE. Intrumen observasi untuk memantau telah dipersiapkan dan dibantu oleh mahasiswa dalam menerapkan ALIHE. Kegiatan pembelajaran dilakukan oleh 4 kelompok yang akan tampil sebagai kelompok yang bertanggung jawab dalam kegiatan pembelajaran.

3. Tahap pelaksanaan tindakan pada tahap 2

Kinerja dosen yang didapat sebagai perbaikan pada tahap 1, diantaranya dosen sudah dapat membangun persepsi dan sikap positif mahasiswa terhadap belajar dan profesi pendidik. Dosen yang telah memiliki kesiapan yang cukup bahwasannya lebih menguasai disiplin ilmu dan sepenuhnya memahami keunikan setiap mahasiswa dengan segenap kelebihan, kekurangan, dan kebutuhannya. Dosen mulai melakukan pengembangan kepribadian dan keprofesionalan sebagai kemampuan untuk dapat mengetahui, mengukur, dan mengembangkan ke- 
mutakhiran kemampuannya secara mandiri, hasilnya masih perlu diperbaiki.

Perilaku dan dampak belajar mahasiswa calon guru yang diperbaiki dari tahap pertama dilihat dari kompetensinya, yaitu mahasiswa mulai dapat mengintegrasikan pengetahuan dan ketrampilan serta membangun sikapnya. Mahasiswa sudah dianggap mampu memperluas serta memperdalam pengetahuan dan ketrampilan serta memantapkan sikapnya. Mahasiswa mampu menerapkan pengetahuan, ketrampilan, dan sikapnya secara bermakna. Mahasiswa mulai mampu membangun kebiasaan berpikir, bersikap dan bekerja produktif. Di samping itu, mahasiswa mampu memahami karakteristik, cara belajar, bekal ajar awal, dan latar belakang sosial kultural peserta didik usia sekolah, khususnya dalam pembelajaran SD. Mahasiswa dirasakan masih belum mampu menguasai prinsip, rancangan, pelaksanaan, dan penilaian pembelajaran yang mencerdaskan, mendidik, dan membudayakan. Mahasiswa belum mampu menguasai strategi dan teknik pengembangan kepribadian dan keprofesionalan sebagai guru.

lklim pembelajaran sudah mengarah pada suasana sudah kelas yang kondusif bagi tumbuh dan berkembangnya kegiatan pembelajaran yang menarik, menantang, menyenangkan dan bermakna bagi pembentukan profesionalitas kependidikan. Di samping itu, suasana kondusif bagi tumbuhnya penghargaan mahasiswa calon guru terhadap jabatan dan kinerja profesional guru.

Materi pembelajaran yang berkualitas disempurnakan dari tindakan pertama. Dapat dilihat dari hasil pantauan diantaranya, materi pembelajaran sudah tersusun secara sistematis dan kontekstual. Materi diarahkan mengakomodasikan partisipasi aktif mahasiswa dalam belajar semaksimal mungkin. Materi disusun dapat menarik manfaat yang optimal dari perkembangan dan kemajuan bidang ilmu, teknologi, dan seni.

4. Tahap perencanaan tindakan kembali

Pada tahap ke dua ini, sudah melakukan kegiatan kelas sambil mengumpulkan data dengan mengisi instrumen atau lembar observasi. Hasil isian Instrumen sebagai perbaikan yang menyempurnakan kegiatan sebelumnya. Dari hasil tersebut di dapat bahwa pembelajaran dengan ALIHE sudah terpenuhi. Oleh karena itu, tidak dilakukan tahap perbaikan tindakan tahap 3.

\section{Pembahasan}

1. Peningkatan Kemampuan Pembelajaran Terkait dengan Perilaku Dosen Atau Pendidik Dalam Pembelajaran IPA SD.
Dosen yang pada tahap awal belum dapat membangun persepsi dan sikap positif mahasiswa terhadap belajar dan profesi pendidik, karena penjajakan awal. Pada kegiatan selanjutnya dosen mampu membangun persepsi dan sikap positif mahasiswa. Dosen selalui dituntut untuk menguasai disiplin ilmu dan dosen yang belum sepenuhnya memahami keunikan setiap mahasiswa dengan segenap kelebihan, kekurangan, dan kebutuhannya, akan berusaha untuk memahami. Dosen biasanya jarang melakukan pengembangan kepribadian dan keprofesionalan sebagai kemampuan untuk dapat mengetahui, mengukur, dan mengembang-mutakhirkan kemampuannya secara mandiri, dengan ALIHE dosen harus melakukan pengembangan tersebut.

2. Peningkatan Kemampuan Pembelajaran Terkait dengan Perilaku Dan Dampak Belajar Mahasiswa Calon Guru Dalam Pembelajaran IPA SD.

Perilaku dan dampak belajar mahasiswa calon guru dilihat dari kompetensinya, ditunjukkan pada mahasiswa sudah memiliki persepsi dan sikap positif terhadap belajar. Mahasiswa belum dapat mengintegrasikan pengetahuan dan ketrampilan serta membangun sikapnya, dengan ALIHE dapat dengan sendirinya mengintegrasikan hal tersebut. Mahasiswa juga mampu mampu memperluas serta memperdalam pengetahuan dan keterampilan serta memantapkan sikapnya. Di samping itu, mahasiswa dapat menerapkan pengetahuan, keterampilan, dan sikapnya secara bermakna. Mahasiswa yang pada awalnya belum mampu membangun kebiasaan berpikir, bersikap, dan bekerja produktif, pada beberapa kegiatan pembelajaran yang menerapkan ALIHE, mereka dapat menerapkannya.

Mahasiswa juga mampu menguasai substansi dan metodologi dasar keilmuan bidang studinya. Mahasiswa juga diarahkan untuk mampu menguasai prinsip, rancangan, pelaksanaan, dan penilaian pembelajaran yang mencerdaskan, mendidik, dan membudayakan. Mahasiswa yang pada awalnya belum mampu menguasai strategi dan teknik pengembangan kepribadian dan keprofesionalan sebagai guru, menjadi mampu untuk menguasai strategi tersebut.

3. Peningkatan Iklim Pembelajaran yang sesuai dengan Mata Kuliah Pendidikan IPA SD.

lklim pembelajaran dengan menggunakan ALIHE menjadikan suasana kelas yang kondusif bagi tumbuh dan berkembangnya kegiatan pembelajaran yang menarik, menantang, menyenangkan, dan bermakna bagi pembentukan profesionalitas kependidikan. Di samping itu pembelajaran yang menggunakan ALIHE membuat suasana kondusif bagi tumbuhnya penghargaan mahasiswa calon guru terhadap jabatan 
dan kinerja profesional guru.

4. Mendesain Materi Pembelajaran dan Media Pembelajaran yang Dapat Meningkatkan Hasil Belajar Mahasiswa PGSD FIP UNJ.

Pembelajaran dengan ALIHE diperlukan kesesuaian dengan tujuan pembelajaran dan kompetensi yang harus dikuasa mahasiswa. Materi pembelajaran harus tersusun secara sistematis dan kontekstual. Materi juga harus dapat mengakomodasikan partisipasi aktif mahasiswa dalam belajar semaksimal mungkin. Melalui ALIHE Materi pembelajaran menjadi menarik dan mempunyai manfaat yang optimal untuk penguasaan perkembangan dan kemajuan bidang ilmu, teknologi, atau seni.

5. Memilih Media Pembelajaran yang lebih sesuai, Khusunya Pada Mata kuliah pendidikan IPA SD.

Dalam ALIHE dituntut untuk memilih media pembelajaran yang lebih sesuai, seperti pada mata kuliah pendidikan IPA SD. Di samping itu, media pembelajaran harus mengarah pada pengalaman belajar yang bermakna. ALIHE juga dapat memfasilitasi proses interaksiantara mahasiswa dan dosen, mahasiswa dan mahasiswa, serta mahasiswa dengan ahli bidang ilmu yang relevan.

\section{PENUTUP}

\section{Kesimpulan}

Berdasarkan hasil dan pembahasan penelitian yang telah dijelaskan, maka dapat disimpulkan bahwa pembelajaran melalui Active Learning In Higher Education (ALIHE) pada mata kuliah pendidikan IPA SD di jurusan PGSD FIP UNJ dapat meningkatan kemampuan pembelajaran terkait dengan perilaku dosen atau pendidik, perilaku dan dampak belajar mahasiswa calon guru, khususnya dalam pembelajaran IPA SD, serta mampu meningkatan kemampuan pembelajaran terkait dengan perilaku dan dampak belajar mahasiswa calon guru dalam pembelajaran IPA SD. Selain itu, dosen atau dosen bersama mahasiswa dapat mendesain materi pembelajaran dan media pembelajaran yang dapat meningkatkan hasil belajar, serta dapat memilih media pembelajaran yang lebih sesuai khususnya pada perkulihan pendidikan IPA pada mahasiswa PGSD FIP UNJ.

\section{Saran}

Berdasarkan kesimpulan yang dihasilkan, maka terdapat beberapa saran untuk penelitian ini: (1) Jurusan PGSD FIP UNJ diharapkan dapat menambah perbendaharaan bidang kajian penelitian tentang ALIHE di PGSD FIP UNJ dan sebagai perbaikan bagi jurusan; (2) mahasiswa PGSD diharapkan dapat meningkatkan kompetensi mahasiswa, khususnya dalam mata kuliah IPA, meningkatkan pemahaman pendidikan IPA di SD, serta mampu menguasai strategi dan teknik pengembangan kepribadian dan keprofesionalan sebagai guru SD; serta (3) dosen selalu upaya meningkatkan kemampuan perilaku pembelajaran yang diaplikasikan dalam kinerjanya dan memberikan layanan pendidikan yang berorientasi pada kebutuhan mahasiswa.

\section{DAFTAR PUSTAKA}

Anomin. (2011). Peningkatan kualitas pembelajaran. Jakarta: DikBud, Dirjen Dikti.

Darmodjo,H., Kaligis, J.R.E. (1991/1992). Pendidikan IPA. Jakarta: Depdikbud.

Dimyati.,\& Mudjiono. (1999). Belajar dan pembelajaran. Jakarta: Rineka Cipta.

Guba., \& Lincoln. (1981). Effective evalution. San Fransisco: Jossey Bass Publisher.

Hidayah, I., \& Krisna, S. (2006). Keefektifan model pembelajaran kooperatif dengan metode penemuan berbantuan Lembar Kerja Siswa (LKS) pada pembelajaran matematika sub materi pokok trigonometri kelas $x$ sma negeri 8 Semarang semester 2 tahun pelajaran. Makalah disampaikan pada tahun 2006

Iskandar, S.M. (1996/1997). Pendidikan IPA. Jakarta: Depdikbud, Dirjendikti.

Miles, B.B., \& A.M. Huberman. (1992). Analisa data kualitatif. Jakarta: UI Press

Sadiman, A.S. (2011). Pembelajaran aktif di perguruan tinggi. Makalah disampaikan pada lokakarya Peningkatan Kualitas Pembelajaran Rintisan Program PPGT, Dirjen Dikti, Kemendikbud, Yogyakarta, 10-13 Desember 2011.

www.teachersnetwork.org. 